\title{
Urban densification in Finland: infill development and building extensions with timber based solutions
}

\author{
Y. Cronhjort ${ }^{1}$, A. Soikkeli ${ }^{2}$, T. Tulamo ${ }^{1} \&$ J. Junnonen ${ }^{3}$ \\ ${ }^{1}$ Department of Architecture, Aalto \\ University School of Arts, Design and Architecture, Finland \\ ${ }^{2}$ Department of Architecture, Oulu University, Finland \\ ${ }^{3}$ Department of Civil and Structural Engineering, \\ Aalto University School of Engineering, Finland
}

\begin{abstract}
Urban densification is one of the pan-European environmental aims along with the 2020 targets for tackling climate change. In Finland, the striving is supported by both temporary regulations and concrete actions, including plans for infill development of town centers. The paper presents and discusses identified barriers and opportunities for the use of timber based solutions for building extensions and infill development in Finland. It is based on the analysis of 13 architectural and engineering master theses published during the past 5 years. The focus is on selected architectural and structural solutions. Environmental, social and economic impacts of the designs are also discussed. The geographical boundary is the Finnish context which is mirrored against European experiences. Keywords: KLIKK, TES Energy Façade, building retrofits, sustainability, urban renewal, wood.
\end{abstract}

\section{Introduction}

The densification of our urban environments is an adopted pan-European target, the main driver being a sustainable development. In Finland, the aim is motivated by the needs of a continuing urbanization and to reduce the environmental impacts of low density urban structures. The revitalization of 
suburbs and urban infill sites presents a potential for development but also a challenge.

European building retrofit and urban renewal practice has demonstrated alternatives for infill development, the extension of building volumes, and the regeneration of built areas including the refurbishment of old buildings. In Finland, large scale realizations are still exceptional and the first town scale plans for urban densification are only now emerging. The development is supported by regulatory actions.

The authors of this paper have been part of several consecutive national and international research and development projects studying and developing timber based solutions for European urban renewal processes. The results are based on research and in total 13 architectural and engineering master theses. The paper presents and discusses identified barriers and opportunities for the use of timber based solutions for building extensions and infill development in Finland.

\section{The Finnish suburb}

Officially Finland has 300 suburbs with a total of 1-1.5 million inhabitants. The biggest building boom started in the late 1960s and continued until the mid1970s with a yearly peak production of more than 70,000 apartments [1]. Still today every fifth apartment is located in multi-storey houses from this era.

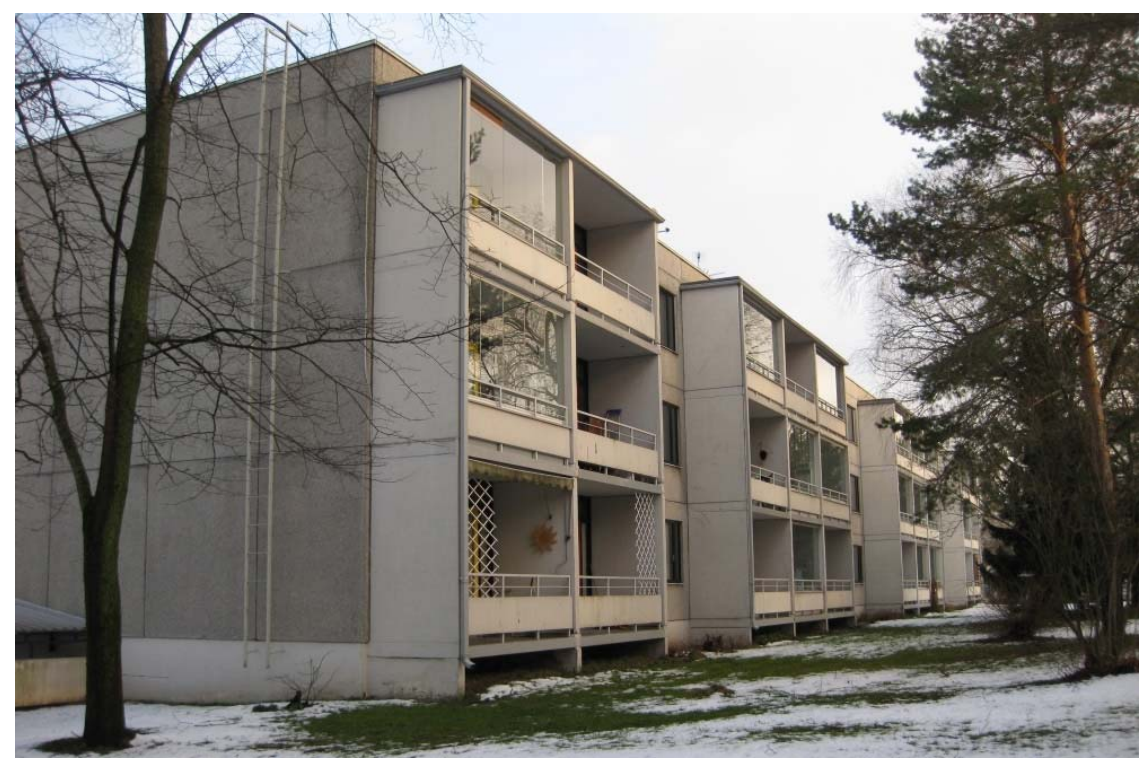

Figure 1: A typical Finnish 3 storey concrete apartment building from the early 1970s. It was built using a load bearing bookshelf frame, nonload bearing facades of concrete sandwich elements and self-load bearing balconies. The glazing is a later addition. Siltamäki, Helsinki. Image Tomi Tulamo. 
The architectural design principles of the 1960s emphasized system thinking and modularity. As a response to rapid urbanization different industrialized systems were developed. In Finland, the BES concrete element system was created and taken into industrial production in the 1960s. It is the predominant building system for apartment housing still today. It is based on predesigned details, prefabricated building elements and an extensive use of concrete. The aim was for an economic and efficient building method. One single building design could be replicated to large scale building developments. The areas were typically built on the ideal of "metsälähiö" ('the forest suburb') resulting in low density urban landscapes [2].

After nearly 50 years, the buildings and areas have reached the end of their life span on technical but also social levels. The total renovation debt of the Finnish building stock was in 2013 estimated to a total of 30-50 billion euros, equal to $10 \%$ of the total value, and growing [3].

\section{Case studies}

The feasibility of timber based extensions and infill development in Finland has been investigated by the authors and in 12 architecture master theses published between 2010 and 2014. The theses were supported as cooperation between the three Finnish universities: Aalto University, Tampere University of Technology and the University of Oulu. An additional master thesis on structural solutions for timber based vertical extensions was published in 2013. The majority of the studied cases are areas with a predominance of concrete element multi-storey apartment buildings from the 1970s - the most topical Finnish housing typology.

In total 13 areas of various size have been investigated. The largest covers 279 hectares of land and the amount of inhabitants ranges from 266 to 7,000 people. The distance to town centres is between 1.5 and 4.5 kilometres. The ownership of the apartments varies with e.g. the majority being owner occupied in Runosmäki, Turku and 72\% rentals in Gammelbacka, Porvoo. The cases were suggested by collaborating towns. Within the areas, exemplary and detailed retrofit plans were drafted for selected single buildings and groups of 3-6 buildings, in total 61 old apartment houses. The represented housing typology consists of 38 three storey buildings $(62.3 \%), 13$ four storey buildings $(21.3 \%), 4$ five storey buildings, 5 six storey buildings and 1 nine storey building.

In common to the buildings is a need for comprehensive refurbishment including building facades and building services. In most cases the buildings lack an elevator and the accessibility needs to be improved. Additionally, current apartment typologies do not necessarily respond to the demand. In all cases, the aim was to investigate how to use timber in the urban context. The use of timber in Finnish townscape is traditional and currently undergoing a revival. 
Table 1: Discussed case areas in Finland are located in the cities of Helsinki, Hämeenlinna, Kouvola, Lahti, Oulu, Porvoo, Riihimäki and Turku. Details according to background information retrieved from collaborating towns.

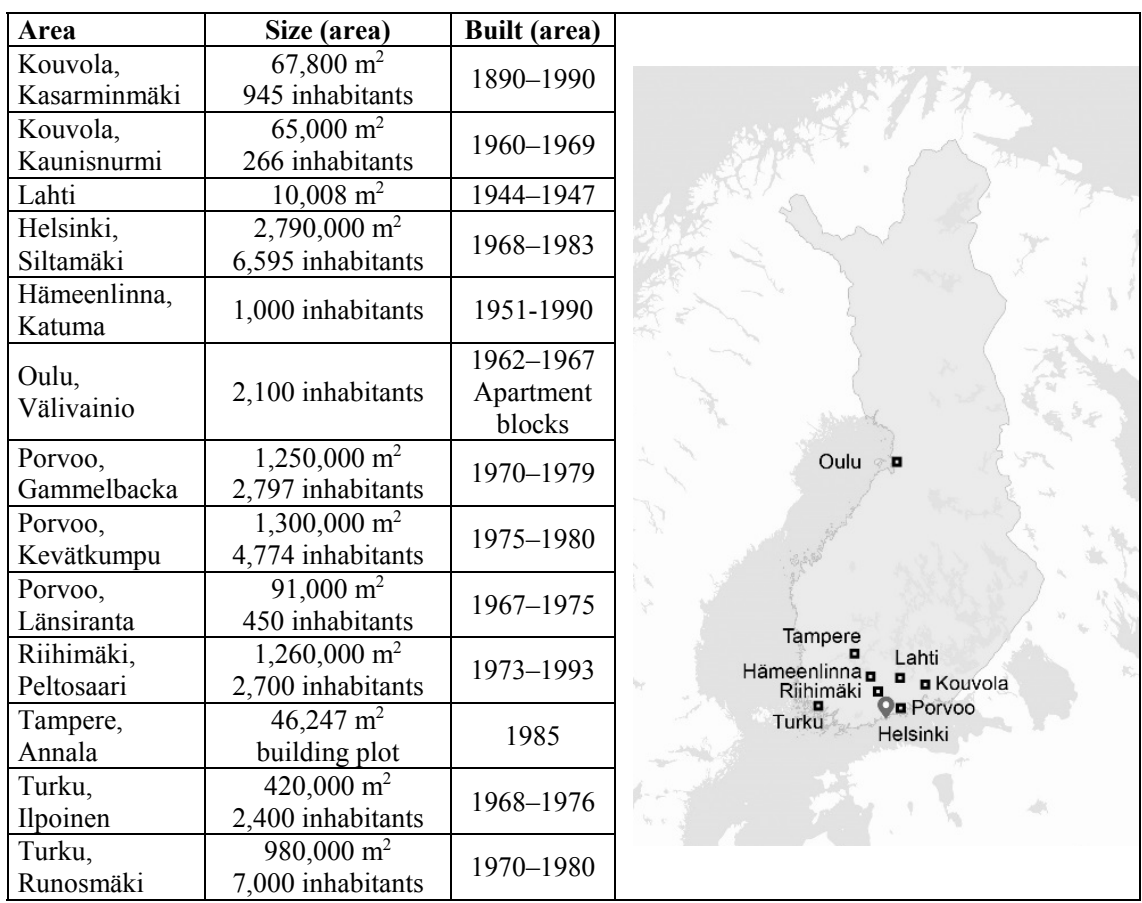

Map by Free Vector Maps, http://freevectormaps.com.

\section{Design for extensions and infill development}

A wish list was given from town planners regarding the development of selected areas. The brief could include e.g. new apartments for families with children, new services but also restrictions. Students decided themselves on the amount of new building volume and typologies. They did not have to respect existing plot boundaries. The final designs present different approaches to infill development and building retrofits. The majority were based on mixed typologies consisting of horizontal and vertical extensions, infill with new building volumes.

\subsection{Architectural design solutions}

The aims for the architectural design of studied areas was to improve the quality of the built environments in the spirit of design for all, infill development and the introduction of building and apartment typologies according to local needs. Additionally, the final designs could include suggestions for environmental improvements like public shared spaces. 
The efficiency of single building plots varied originally from 0.4 to 0.93 . As a result of the suggestive designs the efficiencies increased to in between 0.8 and 1.13. The increase of built volume varied from 6.7 to $80 \%$, with an average new efficiency for single building lots of 0.94 . The efficiency of the whole area was studied only in a few cases, with an original variation between 0.18 and 0.38 . The obtained efficiency for these areas after development would be between 0.3 and 0.53 , with an increase of efficiency in between $40 \%$ and $100 \%$.

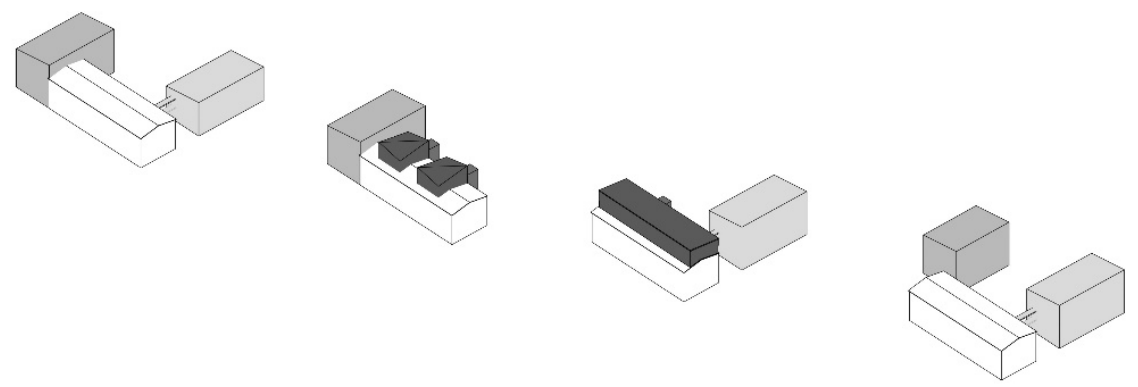

Figure 2: Mixed typologies showing infill development with new building volumes, vertical extensions with both entire new floors and separate volumes, and horizontal extension of existing building volumes. Case Kaunisnurmi, Kouvola. Image Ida Lautanala.

Mixed typologies were used on the level of areas, building plots but also single buildings. Vertical extensions were suggested in 11 out of 13 cases. Horizontal extensions were added in 4 cases and infill with new building volumes in 6 cases. The height of vertical extensions varied between 1 and 2 storeys, even in the same building. No design included more than 2 additional storeys. New floors were designed using either separate small volumes with typically only 1 or 2 new apartments or storeys completely covering the usable area. The maximum relative increase of gross floor area is seen in earlier 3 storey buildings extended with 2 new storeys. All cases were planned to be realized using timber based, prefabricated spatial modules. Suggested new apartments typically added new typologies. A common solution was the creation of family size apartments with apartment specific outdoor areas like roof terraces or large balconies.

Small scale extensions or additions to the old building volumes included in most cases larger, new balconies. In case Annala, Tampere, the design included a suggestion to glaze the old balcony and add new, deeper balconies in between. This was motivated by the good condition of the old balconies and a wish to create more usable private outdoor spaces for the inhabitants. In case Peltosaari, Riihimäki, the design included the addition of new, prefabricated timber based balcony modules attached to the old building structure. Small parasite modules were also suggested in case Gammelbacka, Porvoo.

New additions to an existing context can be designed to either blend in or stand out. In the majority of the presented cases the decision was for the latter. 
New buildings and extensions are timber cladded and framed structures. This was in general motivated by wanting to break the townscape with new elements and the introduction of new materials to an otherwise homogenous environment.

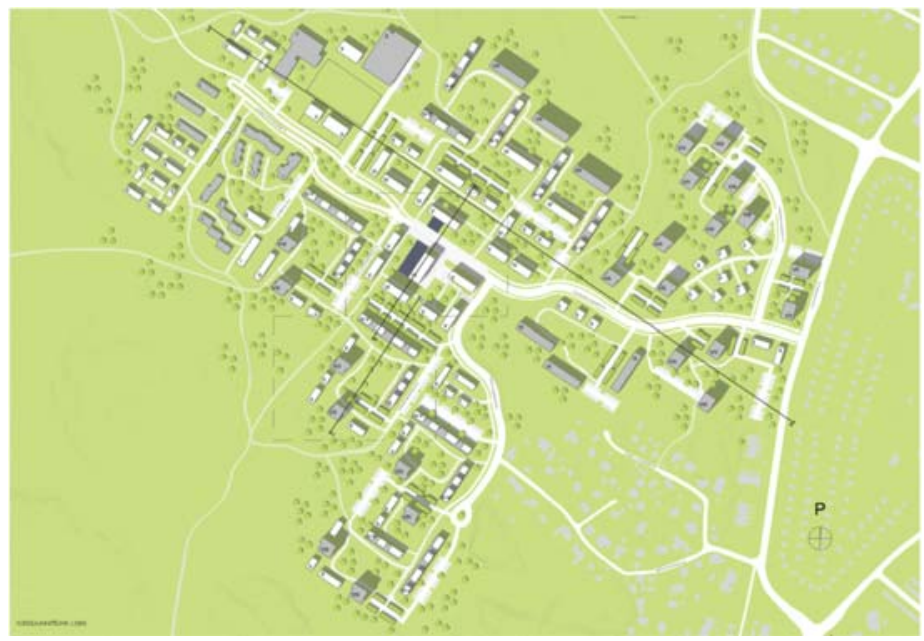

Figure 3: Infill development plan for Ilpoinen, Turku. The efficiency of the area is increased from 0.23 to 0.44 . New additions are shown in white. Design by Katri Palojärvi.

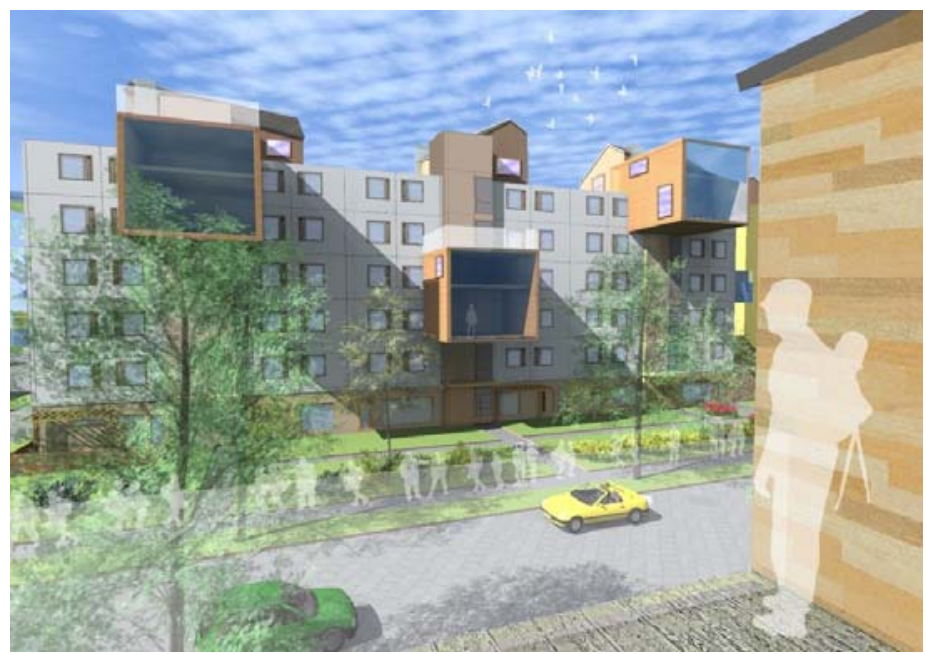

Figure 4: New timber based parasite modules added to old building volume. Case Gammelbacka, Porvoo. Image Sara Pietilä. 


\subsubsection{Circulation systems}

The circulation system of a refurbished building has to respond to the following functional requirements: the integration of an elevator for accessibility, space enough for a staircase that fulfils the regulations for emergency exits and the circulation of possible extensions. Boundaries are set, among others, by the available space and height of old floors.

A new elevator in an existing staircase requires a spacious original staircase or space might have to be gained from apartments. Another option is to solve the circulation through external additions. Based on discussed examples, the new design for circulation system must be solved on a case by case basis as no two building designs are exactly the same. Studied objects were built according to the same structural principle, however, e.g. the ground floor might be situated higher or lower than actual ground level causing design issues.

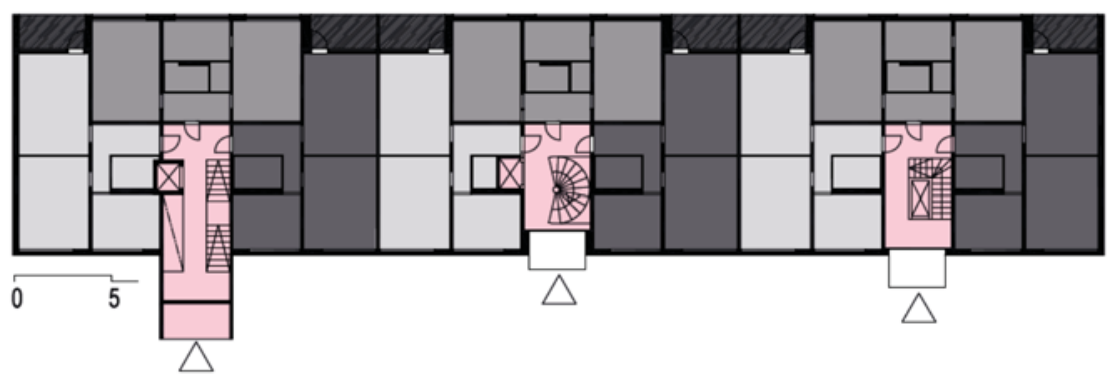

Figure 5: Different circulation system solutions including a new elevator in a typical floor plan. From the left: (1) the new elevator acquires some space from apartments, staircase dimensioned for accessibility, (2) the new elevator completely inside apartments, old staircase, (3) stairs designed according to minimum dimensions and a new elevator placed in the existing circulation space. Case Runosmäki, Turku. Study by Lotta Kindberg.

\subsection{Structural design}

For the structural design of new floors, boundary issues can be the load bearing capacity of the ground and original building structures. In such a case, timber based solutions have an advantage due to their light weight as compared to e.g. concrete structures [4].

The design of vertical extensions was in all discussed cases based on the use of prefabricated spatial modules. Two different structural solutions were employed; structures based on timber frames or CLT (Cross Laminated Timber) based pods. A combination of a CLT frame and separate facade elements was suggested in case Peltosaari, Riihimäki and developed further in the structural engineering thesis.

The final solution is based on the use of three structural elements: (1) A prefabricated intermediate structure on top of the old building; (2) vertical 
extensions using prefabricated spatial modules with a frame of CLT; (3) a thermal insulation layer and cladding added with prefabricated timber based façade elements (TES Energy Facade). Benefits include a fast erection of a building base for the extension building site, sufficient space for new ductwork and sewage systems, and freedom of design for additional floors. The solution allows for building time to connect new service systems to the existing building. Its primary function, however, is to distribute the loads from new, additional floors and structures. It can also serve as an adjustment layer correcting irregularities of the old building volume, not uncommon in existing buildings. The actual addition of new floors and building parts can then be realized efficiently, reducing the total construction time on building site even further [5].

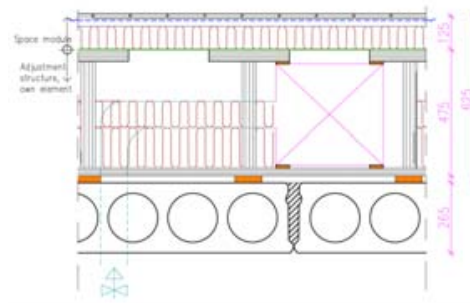

Figure 6: The structural solution of an intermediate structure, the adjustment layer. Drawing Kai Nordberg.

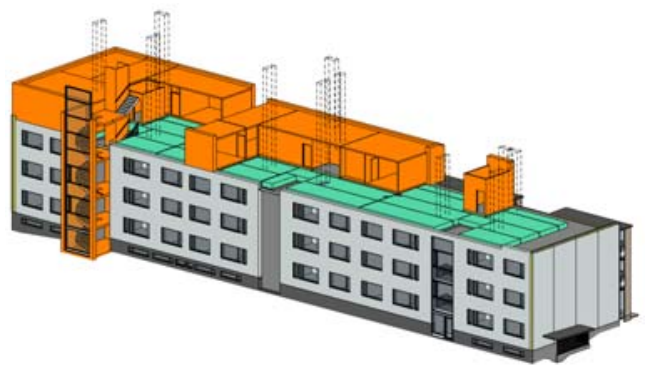

Figure 7: Breakdown structure of the use of prefabricated, timber based spatial modules for a vertical extension. A mediating layer is placed in between old built structure and new floors. The layer acts as adjustment layer, weather protection, building site and space for building services. Case Siltamäki, Helsinki. Image Tomi Tulamo.

\subsection{Building services and energy efficiency}

Improved energy efficiency of our existing building stock is an adopted, panEuropean striving and concerns especially buildings in cold climates. In most of the presented cases an increased thermal insulation, renewed building services and possibly also windows are part of the refurbishment plan for the existing 
buildings. In Finland, a mechanical ventilation system with efficient yearly heat recovery rate is obligatory in new buildings and a necessity when aiming for ambitious levels of energy efficiency in old buildings.

To improve the thermal insulation and airtightness the building envelopes are, in the discussed cases, suggested to be retrofitted with timber based elements (TES Energy Façade) or by state of art solutions. The upgrading and addition of new building services causes a need to solve the integration of new ventilation ducts for incoming fresh air and the integration of new building services for new building parts in old structures, like e.g. the sewage for new storeys. One solution is to integrate ducts in the new façade elements. The ventilation of new floors can be designed according to state of art solutions for new build.

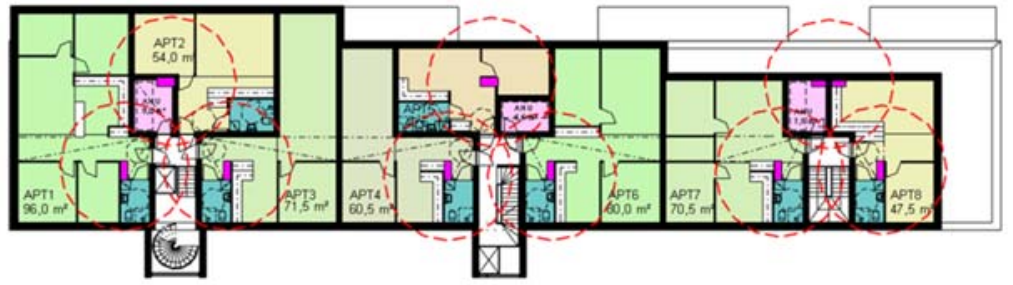

Figure 8: Limitations set by sewage connections for the first extension floor. The plan also shows different options for additional floors: recessed, in line with the existing building volume or extruding. Case Siltamäki, Helsinki. Drawing by Tomi Tulamo.

\section{Design for sustainability}

Sustainability is a concept still lacking clear definitions, standards and assessment methods concerning single building retrofits or urban level renewal [6]. General aims for urban renewal in Finland are set in the development programme for communal structures (2004) according to which the quality of existing environments should be improved with means such as mixed functions, new building close to or within existing urban structures and the support of town centres [7].

\subsection{Environmental choices}

The densification of urban structures as such has environmental benefits like decreased traffic and related carbon dioxide emissions caused by private cars. More specifically, the discussed cases present mainly three actions for decreased environmental impacts of new built, building refurbishments and urban renewal:

(1) Improved energy efficiency of existing buildings as a result of façade retrofits and renewed building services;

(2) Infill development realized as vertical extensions causing no new net land take or use;

(3) The use of timber based structures. 


\subsection{The social viewpoint}

Infill development and urban regeneration of existing areas have social impacts.

Negative impacts can be seen as a public opinion against infill development. People living in old residential areas view infill development, and even the refurbishment of their own building, from the viewpoint of their own home. The need to evaluate potentials, increase knowledge, and interact with the inhabitants is considerably more critical in infill development than in new extension areas. A participatory design process as a means to address locals was tested in six of the theses. In all cases, the meeting of inhabitants and application of SoftGISmethods resulted in a deeper understanding of local issues. The result was seen in the design phase as a striving to improve the quality of living environments and meet the needs of current inhabitants.

Building extensions can also be motivated by social needs and aspirations. For example, apartment houses of three or four storeys from the 1960s and 1970s very seldom have elevators. Added new floors require elevators that concurrently improve the accessibility of existing floors. Added living quality to existing apartments can also be obtained with small scale extensions.

\subsection{Economics}

On communal level, infill development is the cheapest way of growing the city. The expanded user base of existing infrastructure may lead to cost savings of as much as $200-300 € / \mathrm{m}^{2}$ as compared to new construction production. However, infill development projects need to be economically viable for housing companies and construction firms to be launched. A local Finnish challenge is caused by the ownership of buildings. Single people own their apartments and a piece of the land underneath. Together they form housing companies that must take a common decision to build and finance new investments.

Traditionally, redevelopments are financed with a bank loan taken by the housing company. It is then divided according to the occupants' share of the total redevelopment costs. With traditional financial alternatives, many shareholders in a housing company face a tough economic situation. As an example, a professional estimate of the apartment value in the case area of Siltamäki is approximately $2000 € / \mathrm{m} 2$. If the overall renovation costs for a deep refurbishment will be $1000 € / \mathrm{m} 2$, they would cover $50 \%$ of the total apartment value.

Infill development may offer housing companies a way of partially financing large renovation projects by selling a part of their plot or by constructing additional new dwellings. A prerequisite is unused building right on the plot or an adjusted plan as to grant additional rights. However, infill development will act as a financing tool only in the growth areas where the price of the building right is high enough for motivating the occupants and developers.

Another challenge is the parking space issue. If car parks must be built to replace old parking places and provide additional ones, the infill project might not be profitable. The problem shows in the case studies. In discussed 12 architectural master theses the parking was solved inside the building plot in 1 
case, 11 cases needed additional parking space from outside the building plot and in 5 cases a structural parking solution either below or above ground was required.

\section{Discussion and conclusions}

This paper presented the results of studies on the feasibility of building retrofits with timber based extensions for infill development in Finland. In total 13 cases in 8 Finnish towns were analysed and compared.

The feasibility of infill development is demonstrated in selected areas. In common to the projects is a high percentage of suggested new built volume even up to $80 \%$. This shows both the potential for infill development and the low density of current state of Finnish cities.

The feasibility of vertical extensions is also demonstrated. In studied cases more than $60 \%$ out of the 61 single buildings represent three storey high concrete element buildings built in the 1970s. In the majority of the cases this volume was added to with vertical extensions of 1 or 2 storeys, either as single smaller volumes or complete additional storeys.

The functionality of old buildings was also improved by adding new elevators, increasing the accessibility of yards, staircases and sometimes even apartments. Living quality was suggested to be improved by larger or new balconies. Build quality, was enhanced through building refurbishment and retrofit actions supporting increased energy efficiency and improved quality of original building and structures. Impacts on the local community and environment were an underlying premise in all design solutions. An understanding of the needs was supported by introducing a participatory early design process.

Added values of using timber based solutions are demonstrated in all cases. In the majority of the plans timber was allowed visual presence in the townscape and it was added to both existing building volumes and new build. All suggested building extensions were designed using prefabricated, timber based spatial modules and the use of parasite volumes attached to old structures suggest a light weight. The use of CLT allows for a continuous thickness of inner building envelope and an independent external layer of thermal insulation and cladding.

A large volume of infill development is assumed in the majority of the discussed designs. Some cases additionally exemplify small scale redevelopment adding value to existing inhabitants in both economic and social terms.

Infill construction is one of the Finnish national goals in regional and land-use development and presented cases show environmental, economic and social benefits of the solution. However, the success of suburban infill development depends on the ability to identify threats to the area and interests of different stakeholders as well as on the ability to connect different stakeholders to the development process. For example, infill development could be one solution for keeping the services in the area. Infill development can also provide equity financing since housing companies often own inefficiently used land that could be sold to external investors. 


\section{Acknowledgements}

The paper is based on research and student work in the national projects Puun mahdollisuudet Lähiösaneerauksissa (2008-2009) and KLIKK Käyttäjä- ja liiketoimintalähtöinen korjauskonsepti (2012-2014) coordinated by Anu Soikkeli and Jouni Koiso-Kanttila, University of Oulu, and the European project SmartTES (2010-2013). The authors wish to especially acknowledge the work, valuable input and master theses of architects Leeni Harno, Tiina Hotakainen, Tuuli Jäntti, Lotta Kindberg, Reeta-Maria Laine, Ida Lautanala, Niina Murtonen, Katri Palojärvi, Sara Pietilä, Tomi Tulamo, Veli-Pekka Ranta, Marja Vampoulas and structural engineer Kai Nordberg.

Research leading to this publication has received support from the KIINKO Real Estate Education.

\section{References}

[1] Soikkeli, A. (edit.), Puun mahdollisuudet lähiöiden korjauksessa, Oulun Yliopisto, Arkkitehtuurin Osasto, Oulu, 2011. p.35.

[2] Alatalo, E. (edit.), Hurmaava Lähiö Energiatehokas lähiökorjaaminen hankkeen loppujulkaisu, Tampereen Teknillinen Yliopisto, Arkkitehtuurin Laitos, Ympäristöministeriö, 2012.

[3] The Confederation of Finnish Construction Industries RT, website. https://www.rakennusteollisuus.fi/Tietoa-alasta/Korjausrakentaminen1/ Korjausvelka/

[4] Nordberg, K., Additional Wooden Floors to Concrete Element Building, Master thesis, Aalto University School of Engineering, Department of Civil and Structural Engineering, 2013.

[5] Tulamo, T. (edit.), Cronhjort, Y., Riikonen, V., Kolehmainen, M., Nordberg, $\mathrm{K}$, $\mathrm{Hu} \beta$, W., smartTES Innovation in timber construction for the modernisation of the building envelope Book 2 TES Extension, Project report.

http://www.tesenergyfacade.com/downloads/smarttes_b2_Extensions.pdf.

[6] le Roux, S., Ott, S., smartTES Innovation in timber construction for the modernisation of the building envelope Book 6 TES Sustainability, Project report.

http://www.tesenergyfacade.com/downloads/smarttes_b6_Sustainability.

[7] Yhdyskuntarakenteen ohjauksen kehittämisohjelma, Ympäristöministeriö, Yhdyskuntarakenteen ohjauksen kehittämistyöryhmä 30.11.2004, Helsinki. 